\title{
DEVELOPMENT AND APPLICATION OF CREATIVE PROBLEM SOLVING IN MATHEMATICS AND SCIENCE: A LITERATURE REVIEW
}

\author{
Widya ${ }^{*}$, Yeni Nurpatri ${ }^{2}$, Ena Suma Indrawati ${ }^{3}$, Khairul Ikhwan ${ }^{4}$ \\ 1,2,3 Department of Physics Education, STKIP Adzkia, Padang, Indonesia \\ ${ }^{4}$ PGSD, STKIP Adzkia, Padang, Indonesia \\ *Corresponding author: widya@stkipadzkia.ac.id
}

\section{Article Info \\ Article history:}

Received: June 2, 2019

Accepted: March 18, 2020

Published: March 30, 2020

\section{Keywords:}

Aplication

CPS

Development

Literature

Review

\begin{abstract}
The purpose of this study is to review the development and application of creative problem solving learning model especially in the last 1 decades. Research method used in this study was literature review. We collected more than 20 references related to the history, development, and application of the CPS model. Data collection technique used was through literature study. The results of this study obtained some types of CPS models such as CPS version Treffinger, CPS version Osborn, and CPS published by Creative Education Foundation. The CPS model proposed by the Creative Education Foundation is the latest and best model because it was developed to improve the previous CPS model. Each CPS Model has different steps with some similar goals. CPS is applied at several levels of education for learning Natural Sciences and Mathematics. CPS has a significant influence on the achievement of cognitive competence and problem solving skills
\end{abstract}

\section{PENGEMBANGAN DAN PENERAPAN CREATIVE PROBLEM SOLVING PADA PEMBELAJARAN MATEMATIKA DAN ILMU PENGETAHUAN ALAM: SEBUAH REVIEW LITERATUR

Kata Kunci:
Penerapan
CPS
Pengembangan
Literatur
Review
\begin{abstract}
ABSTRAK
Tujuan dari penelitian ini adalah untuk meninjau pengembangan dan penerapan model pembelajaran pemecahan masalah kreatif terutama dalam 1 dekade terakhir. Metode penelitian ini adalah kajian pustaka, mengumpulkan lebih dari 20 jurnal terkait sejarah, perkembangan, dan penerapan model CPS. Teknik pengumpulan data adalah melalui studi literatur. Hasil penelitian ini: diperoleh beberapa jenis model CPS seperti Treffinger versi CPS, versi CPS Osborn, dan CPS yang diterbitkan oleh Creative Education Foundation. Model CPS yang dikemukakan oleh Creative Education Foundation merupakan model yang tebaru dan terbaik karena dikembangkan untuk memperbaiki model CPS sebelumnya. Setiap Model CPS memiliki langkah yang berbeda dengan beberapa tujuan serupa. CPS diterapkan di beberapa tingkat pendidikan untuk pembelajaran IPA dan Matematika. CPS memiliki pengaruh yang signifikan terhadap pencapaian kompetensi kognitif dan keterampilan pemecahan masalah.
\end{abstract}




\section{INTRODUCTION}

\subsection{Overview CPS}

Teachers as facilitators in learning are expected to create an atmosphere of learning that can encourage students to be critical and creative in solving problems [1]. Teacher must be able to develop learning so that students will learn optimally [2]. Teacher must understand various learning models that can develop students' creativity [3]. Creative Problem Solving Model is a learning model that can increase students' creativity [4]. Creativity and critical thinking are 2 components that have an important role in creative problem solving [5]. Creativity can arise from the interaction between reasoning ability and the core that produces something real, meaningful, and novelty [6]. Creativity depend on three factors: 1) personal structure of an individual is confronted with a creativity condition, 2) the structure of the given creative situation, 3) some meomentary circumstances that mat be favourable [7]. Everyone can achieve different creative and productive levels [8]. Through creativity, people can find new solutions to face problems [6]. Based on some of the explanations above, it can be concluded that CPS is a learning model that can help increase student creativity.

Before we discuss more deeply about CPS, we must know about the correlation between CPS and problem-solving. The problem means differences in expectations and reality [8]. We must change the concept of a problem that is usually synonymous with negative connotation into an interesting challenge to be tackled [9]. Creativity and problem solving are interrelated and interconnected, creativity activity appears simply to be a special class of problem solving characterized by novelty, unconventionality, persistence, and difficulty in problem formulation [8]. CPS derived from three words: creative means a lot of new and unique ideas to create solutions, problem means a condition that provides challenges and interrelated opportunities, solution means designing ways to answer or find solutions to a problem [10]. CPS is a methodology framework designed to help solve problems by using creativity in achieving goals and improving thinking skills [8]. CPS is a proven method for solving imaginative and innovative problems [11]. So that, CPS can be defined as the ability to plan a unique way or idea to solve a problem.

CPS can be applied in various conditions and all ages [12]. CPS can be applied easily in learning process [13]. Everyone has a different level of creativity, style, and way of applying the CPS learning model [14]. The main principles of CPS are: 1) divergent and convergent thinking must be balanced, 2) asking the problem as a question, 3) Defer or suspend judgment [8]. CPS starts with two assumptions: everyone has creative potential and creative skills can be learned and improved [14]. CPS needs to be supported by a learning environment that can empower students to learn actively [15]. CPS can stimulate people to think creatively, because everyone has the potential to be creative.

\subsection{History of CPS Developing}

Alex Osborn was the first expert to care about CPS learning in 1953. He was very concerned in promoting creativity to find new solutions that were useful in developing opportunities to fix any problem [14]. In the middle of 1950s until 1970s, Osborn and his friends tried to disseminate the concept of this model (CPS) to applicants (graduate and undergraduate level) [8]. The CPS model continued to be revised and refined in the 1970s and 1980s, based on advice from pioneer Osborn and CPS developers and researchers in "the first generation". Osborn applied CPS when teaching and in his work as advertising work. After Osborn's death, research on CPS was followed by juniors who joined the Buffalo Project (Parners, Noller, Treffinger, etc) [4]. 
In another journal, Treffinger explained the steps to develop CPS: 1) started at 1942 - 1967: the first model CPS, 2) 1963 - 1988: the creative student project, 3) 1981 - 1986: increased balancing of diverging and converging, 4) 1987 -1992: CPS developed an clustered, 5) 1992 -1994: introduced approach for CPS, and 6) 1994 - present: integration of CPS [4]. CPS has changed in its development, including: 1) the process of solving problems naturally, 2) changes in the prescriptive to descriptive approach, 3) becoming more flexible and responsive to the task [14]. So, in this article, we will discuss the development and application of CPS at several levels of education and their impact on educational development. After 1980, the CPS Framework was created and developed through research, development, and field experience in many subjects, for example: mathematics, computers, and engineering [16]. Currently, there is an organization that specializes in research on CPS. This organization is the Creative Education Foundation. This organization houses CPS experts who always share best practices and develop in creative studies.

This research was conducted to describe the history, development, and application of CPS in learning. CPS is a learning model that can upgrade students' critical thinking skills and creative problem solving skills [17]. CPS has been applied at various levels of education and various fields of science. This article contains CPS history, CPS development, and CPS applications. This article collects some of the results of research on CPS, the effects of CPS in learning mathematics and science.

\section{METHOD}

This article aims to describe history, development, and application of CPS in several countries and education levels. Data collection techniques used in this study is study literature/literature review. This literature review is a collection of history, development, and application of CPS taken from several sources (proceedings, journals, and books). The flow of this literature review can be seen in the Figure 1

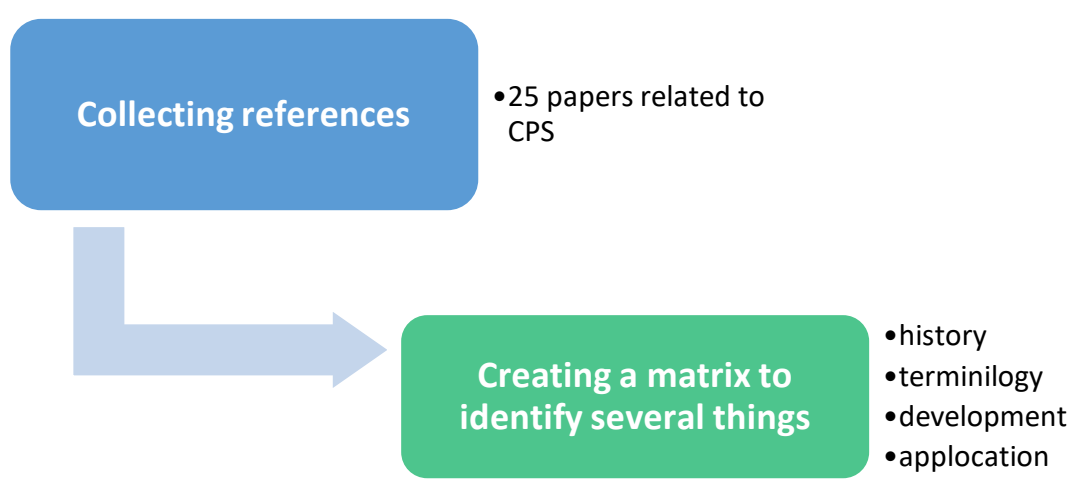

Figure 1. Flow of This Literature Review

This review literature takes 2 weeks for collecting the sources ( 25 journals related to the focus to be read, making matrices identify some things, and write in the form of scientific work) [18].

108 Indonesian Journal of Science and Mathematics Education 


\section{RESULTS AND DISCUSSION}

This article aims to explain some of the studies using the CPS model, try to compare them, and see the effectiveness of the application in several studies. Data collection techniques used in this study is study literature. In this article, writers tried to get some theories about CPS in many literatures.

\subsection{Types of CPS Models}

\section{Osborn-Parnes Problem-Solving Model}

The syntacs of this Osborn-Parnes problem-solving model written by Isaksen and Mitchel Kowalik are:

a. Mess Finding is an attempt to identify conditions that give rise to challenges;

b. Data Search is an attempt to identify all important facts that are known to be related to the situation

c. Finding Problems is an attempt to identify all possible problems and then to formulate the most basic problems

d. Idea findings are attempts to identify as many solutions as possible for problems that have been formulated.

e. Solution Finding uses a list of selected criteria to choose the best solution for action.

f. Acceptance Finding: make every effort to get acceptance for a solution [10].

Osborn suggests using this model in group learning, because the most effective problems are solved in teams, where brainstorming allows more ideas to be generated.

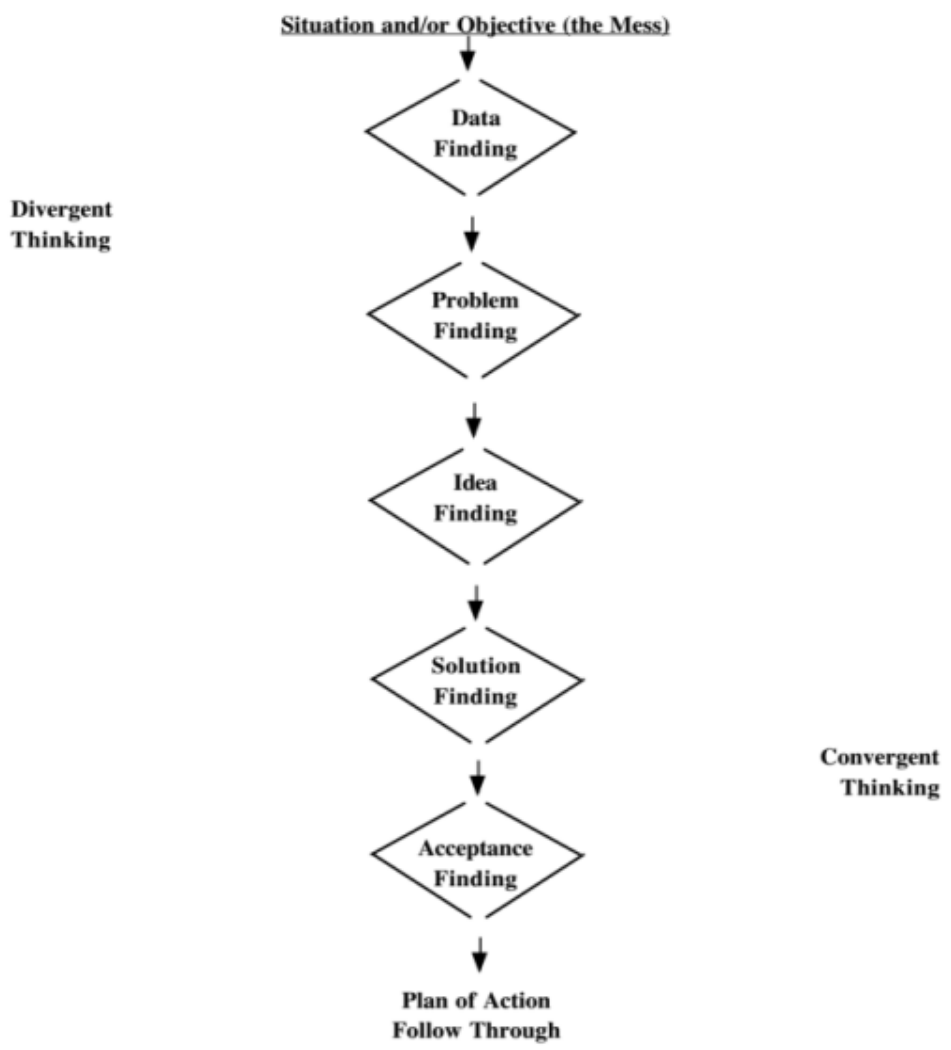

Figure 2. Syntacs Of Osborn-Parnes Problem-Solving Model (Note: Created by Treffinger and Isaksen)

To find data and solutions, it is recommended to process ideas about all known facts. In finding problems, we are advised to use convergent thinking to assess and choose the most basic problems. At the acceptance stage, it is recommended to use different thinking 
skills by making a list of responses that appear. At the acceptance stage it is recommended to use convergent thinking [10].

Osborn continued to learn about this model and apply it when teaching. In 1965, Osborn and his friends tried to apply CPS in all aspects of their lives. And then, he developed the new release of CPS version 2.0. After being extensively tested with a two-year experiment, Osborn wrote it in two books: The Creative Behavior Handbook and the Creative Behavior Workbook. In 1978, Ruth Noller revised the last chart about CPS, he revised 6 steps into 5 steps of CPS [8]. In the middle of 1979, Osborn released new version of CPS: CPS Version: 2.2

\section{OSBORN-PARNES FIVE-STAGE CPS MODEL ( 2.2$)$}

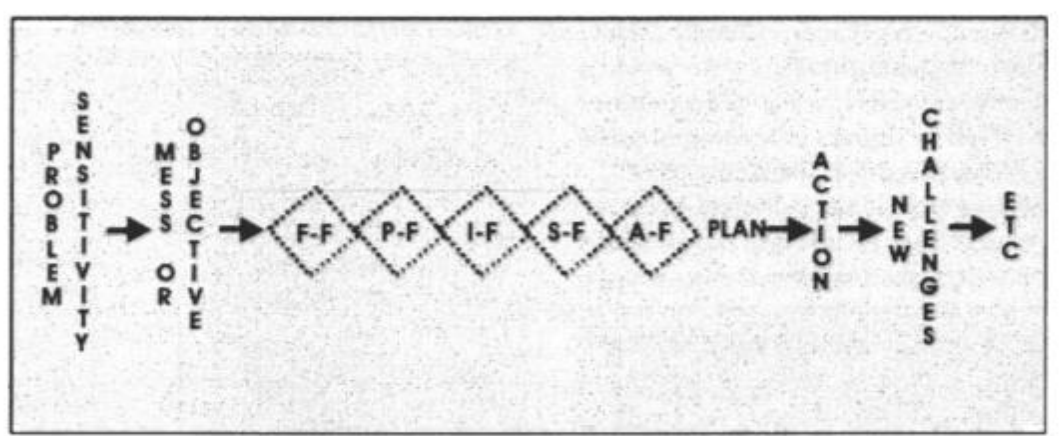

Figure 3. Osborn-Parnes-5-Stage CPS Model (Version 2.2) (Note: Created by Treffinger and Isaksen)

\section{CPS Model by Treffinger dan Isaksen}

Treffinger and Isaksen started to study about CPS in 1983.

a. Version 2.3: Treffinger changed about horizintal to vertical layout [19], [20]

b. Parner popularized CPS and integrated by concept such imagery amd visualization [19], [20])

c. Version 3.0: pointed about dynamic balance between creative and critical thinking [19], [20]

d. Version 4.0 : pointed about flexibility and more natural of process aplications ([19], [20]

e. Version 5.0 and 5.1: in version 5.0, Iskasen started to frame and document new direction for a descriptive, view, and applications of CPS. In version 5.1 Treffinger added a new improvement of metacomponent (planning, monitoring, managing, modifying) behavior during CPS [8], [19]

f. Version 6.0 and 6.1: version 6.0 has different language with all previous versions: the understanding the challenge and generating idea. Version 6.1 pointed CPS as a system and applicable frame work for process to help design and develop new and useful output [8], [19]

Version $6.1^{\mathrm{TM}}$ is the last version of Treffinger and team. In his article, Treffinger and Isaksen have written version 6.1: CPS is proven effective and has an impact on the ability and habits of thinking, the CPS process tends to be easy to learn and easy to use by individuals and groups of various ages, integrated in many organizational activities, dealing with daily problems [8] 


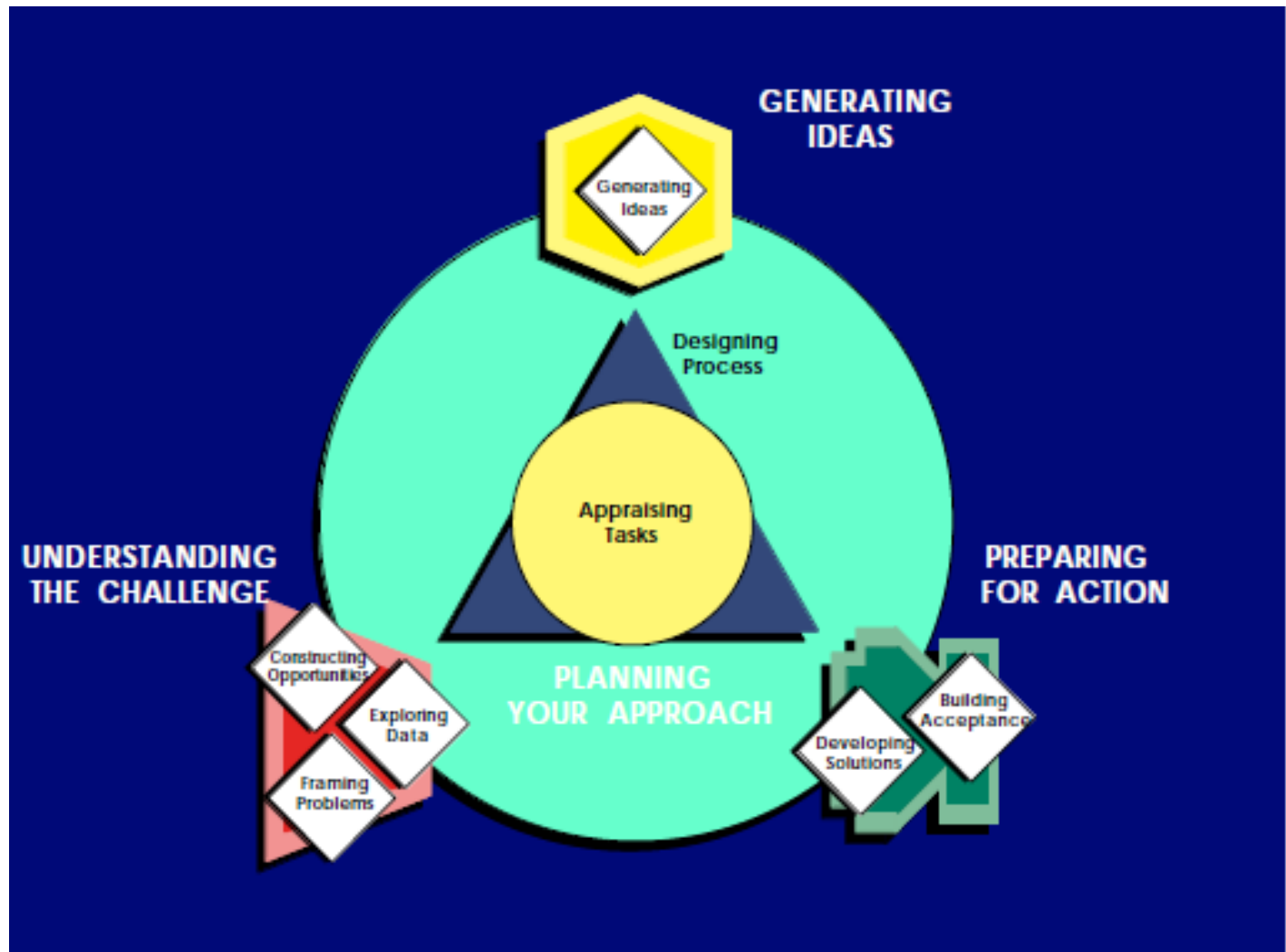

Figure 4. The Creative Problem Solving Framework Version 6.1 ${ }^{\mathrm{TM}}$ (Note: Created by Donald J. Treffinger, Scott G.Isaksen, and K.Brian Dorval)

Based on the figure above, we can be seen that CPS version $6.1^{\mathrm{TM}}$ has 4 stages that can be seen in the Table 1.

Table 1. Information of Each Stage of CPS Version 6.1 $1^{\mathrm{TM}}$

\begin{tabular}{|c|c|}
\hline Stages & Information \\
\hline Understanding the Challenge & $\begin{array}{l}\text { Investigating, clarifying, formulating, or focusing a goal, challenge to } \\
\text { make our direction clear. Constructing opportunities helps you focus, } \\
\text { exploring data helps you identify key elements, and framing problem } \\
\text { helps you to express your problem }\end{array}$ \\
\hline Generating Ideas & $\begin{array}{l}\text { An open, search ideas (varied, flexible, unusual, and novelty). } \\
\text { Generating idea help you to break away from limited assumptions }\end{array}$ \\
\hline Preparing for The Action & $\begin{array}{l}\text { Exploring ways to make promising options into good solution and } \\
\text { preparing successful application. Developing solution helps you to use } \\
\text { practical tools, building acceptance help to implement creative ideas }\end{array}$ \\
\hline Planning Approach & $\begin{array}{l}\text { To make sure your ways into direction you want to go. Apprising task } \\
\text { help you to get best from persons, resources, and methods. Designing } \\
\text { process helps you choose and use the components, stages, or tools that } \\
\text { match for you reach your goals. }\end{array}$ \\
\hline
\end{tabular}

\section{CPS Model by Creative Education Foundation}

This CPS pointed in divergent thinking and convergent thinking. Different thoughts: produce lots of ideas and choices, and convergent thoughts: evaluate ideas and choices, and make decisions stage of this model are four stage with six explicit steps: 


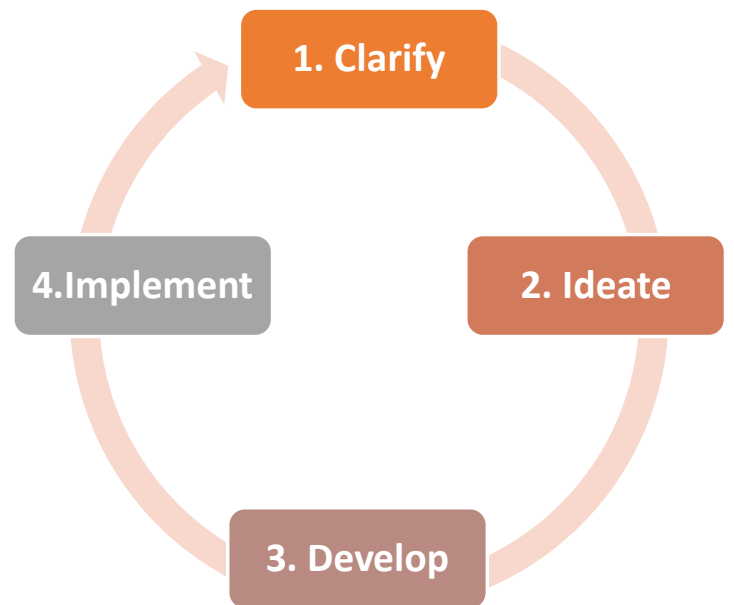

Figure 5. Stages of CPS Model by Creative Education Foundation (Note: Created by Creative Education Foundation)

Information about stage and step of CPS can be seen in Table 2.

Table 2. Stages and Steps of CPS by Creative Education Foundation

\begin{tabular}{|c|c|c|}
\hline Stage & Step & Purpose \\
\hline \multirow[t]{3}{*}{ Clarify } & Explore the vision & Identify goals, expectations, or challenges \\
\hline & Collect the data & $\begin{array}{l}\text { Explain and produce data to enable a clear } \\
\text { understanding of challenges }\end{array}$ \\
\hline & Formulate Challenges & $\begin{array}{l}\text { Sharpen awareness of challenges and create } \\
\text { challenging questions that invite solutions }\end{array}$ \\
\hline Ideate & Explore ideas & Generate ideas that answer the challenge questions \\
\hline Develop & Formulate a solution & $\begin{array}{l}\text { To move from ideas to solutions, evaluate, } \\
\text { strengthen, and select solutions for best "fit" }\end{array}$ \\
\hline Implement & Formulate a Plan & $\begin{array}{l}\text { Explore the acceptance and identification of } \\
\text { resources and actions that will support the } \\
\text { implementation of the chosen solution }\end{array}$ \\
\hline
\end{tabular}

\subsection{Implementation of CPS in Mathematical and Science Learning}

\section{CPS Application for Shahid Chamran University Students}

This research was conducted by Alireza Hajiyakhchali (Assistant Prof. of Shahid Chamran University). The focus of his research is the effect of CPS on academic student welfare. The type of CPS that was applied in his research was CPS version 6.0. The variables of this research are: 1) the effect of CPS in schools, 2) perceptions of academic achievement, 3) self-reports of disruptive behavior. This research is an experimental research. The results of this study are: 1) there is a significant difference in the academic level between the control class and the experimental class, 2) Improve in the academic field is felt more in students in the experimental group than students in the control group. The results of this study indicate that the application of CPS learning strategies significantly increases academic achievement [21].

\section{CPS Application in Mathematical Adaptive Reasoning of Students}

This research was conducted by Muin, Hanifah and Diwidian from the Hidayatullah State Islamic University Syarif. The purpose of this study was to analyze the influence of the creative problem solving learning model (CPS) on mathematical adaptive reasoning. The type of CPS used was adapted from Mitchell and Kowalik. The method used in this 
study was quasi-experimental with the experimental group and the control group. In the experimental group the treatment was given in the form of learning using the Creative Problem-Solving learning model, while the control group was treated using conventional learning. The results of this study are: 1) students' mathematical adaptive reasoning skills taught by the CPS model are higher than students' adaptive reasoning skills from those taught by conventional models, 2) the most interesting aspects of adaptive reasoning through CPS are intuitively inductive, 3 ) CPS can provide the development of overall mathematical adaptive reasoning skills [22].

\section{CPS Application for Statistics Teaching}

This research was conducted by Ridong Hu, Su Xiaohui, and Chich - Jen Shieh from Huaqiao University, China. The type of this research is a quasi-experimental. The results revealed that 1) learning outcomes with CPS showed a much higher cognitive component than general teaching, 2) CPS showed a higher affective component than general teaching, 3) CPS showed a much higher component of behavioral tendencies than general teaching. According to the results, it shows that students provide positive responses to CPS learning. The combination of CPS in teaching statistics provides a positive complementary effect [23]

\section{Research on the Impact of Metacognitive Instructions on CPS}

This research was conducted by A. Hargrove from University of Kentucky and John L. Nietfeld from North Carolina State University. This study aims to look at the impact of teaching creativity in the form of associative thinking strategies within the metacognitive framework. The results of this study are: 1) After completing the course, the experimental group has a higher score than the others, 2) The inventory score of metacognitive awareness increases for the treatment group that affects students' ability to solve student problem[24]

\section{Research on Development of CPS-Integrated Learning Materials}

The purpose of this study is to produce learning tools that are integrated with the CPS model that has valid, practical and effective criteria. CPS model applied in the teaching materials is the CPS adopted by Mitchel and Kowalik. The results of this study are: 1) Learning tools developed are in very valid category with equal to $86.38,2$ ) Learning tools developed are in very practical category with 92.93 with very practical category, 3) learning tools developed very effectively proven with average student score of 86.11 [16]. In addition, Widya also tried to develop science teaching materials in 2019. In this study it was found that the developed science teaching materials have a valid, practical category, and are able to improve student learning outcomes [25]. Based on this research, CPS can be integrated directly into the learning device. CPS can improve student learning outcome.

Septiana Wijayanti from Widya Dharma University, Klaten tried to develop learning materials based on CPS. This study aims to develop Mathematics learning tools based on the CPS model. The research products obtained were in the form of Learning Implementation Plans, Modules, and Student Worksheets. The results obtained in the form of: learning tools that are developed are included in both categories (asking experts), teachers and students who use these learning devices show good responses, and effective learning tools used in learning [26]

CPS has been developed since 70 years ago. Research on CPS is also continuing. The CPS was revised several times with revisions based on research and needs analysis. At the beginning of CPS, CPS was only applied in the learning process, but after the 
revision and CPS can be used in various aspects of life. This is in line with those submitted by Treffingger and Isaksen that CPS can be applied in various aspects of life. The basic difference between older versions of CPS with contemporary CPS are: 1) Older version assumed that problem are something difficult and wrong, while new version assumed that problems are challenge and opportunities, assuming the problem is a challenge will increase the spirit in solving the problem, 2) old version depends on skillful only, while in new version people can use their knowledge and skill to solve the problems. This is consistent with that described by treffinger that the older version depends only on skill [19].

Based on some versions of CPS described in this paper, the number of stages in each version is different, but there are several stages that have similar goal. The following describes the similarities of some versions of the CPS model.

Table 3. Matrix Similarity of Purpose some Version of The Model CPS

\begin{tabular}{|c|c|c|c|}
\hline Aim the stage & Osborn & Treffinger & $\begin{array}{c}\text { Creative Education } \\
\text { Foundation }\end{array}$ \\
\hline To understand condition & $\begin{array}{l}\text { Fact Finding: identify } \\
\text { situation }\end{array}$ & $\begin{array}{l}\text { Constructing } \\
\text { opportunity }\end{array}$ & Explore vision \\
\hline To identify the goals & Data Finding & Exploring data & Gather data \\
\hline $\begin{array}{l}\text { To formulate the } \\
\text { problem }\end{array}$ & Problem finding & Framing problem & Formulate the Challenges \\
\hline To generate idea & Idea finding & Generating idea & Explore ideas \\
\hline To choose the solution & Solution finding & $\begin{array}{l}\text { Developing solution } \\
\text { and building } \\
\text { acceptance }\end{array}$ & Formulate the solution \\
\hline To implement & Acceptance finding & Design process & Formulate a plan \\
\hline
\end{tabular}

Based on Table 3 above, we can see that CPS version has different stages but has the same purpose. the general purpose of each stage of CPS are to understand condition, to identifying the goals, to formulate the problem, to generate idea and to implement.

CPS has been revised several times. CPS revision is based on weaknesses of the previous type. The latest CPS was introduced by the Creative Education Foundation which has 4 steps: clarify, ideate, develop, and implement[11]. Basically, these four steps aim to: understand conditions, indicate objectives, formulate problems, gather ideas, choose solutions, and implement. This type of CPS tries to combine divergent thinking and convergent thinking. A lot of research on CPS has been carried out mainly in the study of Science and mathematics. Most research is done on senior high Scholl and university, but CPS can also be applied in the elementary school, business and consulting organization [11].

\section{CONCLUSION}

CPS is a learning model that is able to train and increase student creativity. CPS has been developed since 1953, and since then, the CPS has undergone several changes/developments. The purpose of each CPS step is to: understand conditions, understand objectives, formulate ideas, formulate solutions, implement, and evaluate. CPS has been applied in learning at several levels of education. CPS is considered effective in helping students achieve their learning goals. Then, CPS can also be used as a basis for developing valid, practical and effective learning tools. 


\section{REFERENCES}

[1] Widya, R. Rifandi, and Y. Laila Rahmi, "STEM education to fulfil the 21 st century demand: a literature review," J. Phys.: Conf. Ser., vol. 1317, p. 012208, Oct. 2019, doi: 10.1088/1742-6596/1317/1/012208.

[2] W. Widya, E. S. Indrawati, and D. E. Mulyani, "Preliminary analysis of learning materials development based on creative solving model integrated by anticorruption characters," Proceeding ASEAN Youth Conference, Oct. 2019, Accessed: May 03, 2020. [Online]. Available: http://jurnal.aycppim.id/index.php/ayc/article/view/7.

[3] K. Soh, "Fostering student creativity through teacher behaviors," Thinking Skills and Creativity, vol. 23, pp. 58-66, Mar. 2017, doi: 10.1016/j.tsc.2016.11.002.

[4] S. G. Isaksen, G. J. Puccio, and D. J. Treffinger, "An Ecological Approach to Creativity Research: Profiling for Creative Problem Solving," The Journal of Creative Behavior, vol. 27, no. 3, pp. 149-170, 1993, doi: 10.1002/j.21626057.1993.tb00704.x.

[5] S. M. Wechsler et al., "Creative and critical thinking: Independent or overlapping components?," Thinking Skills and Creativity, vol. 27, pp. 114-122, Mar. 2018, doi: 10.1016/j.tsc.2017.12.003.

[6] C. R. Aldous, "Creativity, problem solving and innovative science: Insights from history, cognitive psychology and neuroscience," p. 12.

[7] "A Creative Problem Solving Process* - CACKOWSKI - 1969 - The Journal of Creative Behavior - Wiley Online Library." https://onlinelibrary.wiley.com/doi/abs/10.1002/j.2162-6057.1969.tb00127.x (accessed Apr. 10, 2020).

[8] D. J. Treffinger, E. C. Selby, and S. G. Isaksen, "Understanding Individual ProblemSolving Style: A Key to Learning and Applying Creative Problem Solving," Learning and Individual Differences, vol. 18, no. 4, pp. 390-401, 2008, doi: 10.1016/j.lindif.2007.11.007.

[9] "The challenge of transformative learning: mining practice stories to study collaboration and dispute resolution strategies: The Challenges of Collaboration in Environmental Governance.' https://www.elgaronline.com/view/edcoll/9781785360404/9781785360404.00027.x $\mathrm{ml}$ (accessed May 03, 2020).

[10] A. Guevara, "Creative Problem Solving-Mitchell \&amp; Kowalik," Accessed: Aug. 21, 2018. [Online]. Available: https://www.academia.edu/8707593/Creative_Problem_SolvingMitchell_and_Kowalik.

[11] Creative Education Foundation., Creative Problem Solving Resource Guide. Creative Education Foundation., 2014.

[12] "Creative Problem Solving: Overview and educational implications | SpringerLink." https://link.springer.com/article/10.1007/BF02213375 (accessed Apr. 10, 2020).

[13] "The Process of Solving Complex Problems by Andreas Fischer, Samuel Greiff, Joachim Funke :: SSRN." https://papers.ssrn.com/sol3/papers.cfm?abstract_id=2097374 (accessed May 03, 2020).

[14] "Creative Problem Solving: The History, Development, and Implications for Gifted Education and Talent Development - Donald J. Treffinger, Scott G. Isaksen, 2005." https://journals.sagepub.com/doi/abs/10.1177/001698620504900407 (accessed Apr. 10, 2020). 
[15] H. Kashefi, Z. Ismail, and Y. M. Yusof, "Supporting Engineering Students' Thinking and Creative Problem Solving through Blended Learning," Procedia - Social and Behavioral Sciences, vol. 56, pp. 117-125, Oct. 2012, doi: 10.1016/j.sbspro.2012.09.638.

[16] W. Widya, H. Hamdi, and A. Fauzi, "Kualitas perangkat pembelajaran fisika berbasis model creative problem solving dengan pendekatan open-ended pada materi usaha dan energi terintegrasi energi biomassa," Gravity : Jurnal Ilmiah Penelitian dan Pembelajaran Fisika, vol. 3, no. 2, Jul. 2017, Accessed: Aug. 29, 2018. [Online]. Available: http://jurnal.untirta.ac.id/index.php/Gravity/article/view/2600.

[17] M. Masrukan, A. J. Parotua, and I. Junaedi, "The ability of mathematical creative thinking viewed from student learning interest of class VIII in learning CPS contextual approach," Unnes Journal of Mathematics Education, vol. 8, no. 1, pp. 58-64, Mar. 2019, doi: 10.15294/ujme.v8i1.24745.

[18] E. Triandini, S. Jayanatha, A. Indrawan, G. W. Putra, and B. Iswara, "Metode Systematic Literature Review untuk Identifikasi Platform dan Metode Pengembangan Sistem Informasi di Indonesia," Indonesian Journal of Information Systems, vol. 1, no. 2, pp. 63-77-77, Feb. 2019, doi: 10.24002/ijis.v1i2.1916.

[19] D. J. Treffinger, S. G. Isaksen, and K. B. Stead-Dorval, Creative Problem Solving: An Introduction. Prufrock Press Inc., 2005.

[20] S. G. Isaksen, K. B. Dorval, and D. J. Treffinger, Creative Approaches to Problem Solving: A Framework for Innovation and Change. SAGE Publications, 2010.

[21] A. Hajiyakhchali, "The Effects of Creative Problem Solving Process Training on Academic Well-being of Shahid Chamran University Students," Procedia - Social and Behavioral Sciences, vol. 84, pp. 549-552, Jul. 2013, doi: 10.1016/j.sbspro.2013.06.602.

[22] "The effect of creative problem solving on students' mathematical adaptive reasoning - IOPscience." https://iopscience.iop.org/article/10.1088/17426596/948/1/012001/meta (accessed Apr. 10, 2020).

[23] R. Hu, S. Xiaohui, and C.-J. Shieh, "A Study on the Application of Creative Problem Solving Teaching to Statistics Teaching," EURASIA J MATH SCI T, vol. 13, no. 7, Jun. 2017, doi: 10.12973/eurasia.2017.00708a.

[24] R. A. Hargrove and J. L. Nietfeld, "The Impact of Metacognitive Instruction on Creative Problem Solving," The Journal of Experimental Education, vol. 83, no. 3, pp. 291-318, Jul. 2015, doi: 10.1080/00220973.2013.876604.

[25] W. Widya, E. S. Indrawati, D. E. Muliani, and M. Ridhatullah, "Design of Integrated Science Learning Materials Based on Creative Problem Solving Model Integrated with Anti-Corruption Characters," Kasuari: Physics Education Journal (KPEJ), vol. 2, no. 2, pp. 62-69, Dec. 2019, doi: 10.37891/kpej.v2i2.103.

[26] "Pengembangan Perangkat Pembelajaran mengacu Model Creative Problem Solving berbasis Somatic, Auditory, Visualization, Intellectually | Wijayanti | AlJabar: Jurnal Pendidikan Matematika." http://ejournal.radenintan.ac.id/index.php/aljabar/article/view/1941/1552 (accessed May 03, 2020). 